\author{
Вадим ПРОКОПОВ, \\ orcid.org/0000-0001-5120-9419
}

аспірант кафедри історії України Дніпровського національного університету ім. Олеся

Гончара, науковий співробітник Інституту суспільних досліджень

(Дніпро, Україна) vadim.prokopov@gmail.com

\title{
ХВОРОБИ ТА ЇХ ЛІКУВАННЯ В ЖИТТІ УКРАЇНСЬКИХ ПОВСТАНЦІВ ЗАКЕРЗОННЯ (1944 - 1947 рр.)
}

У статті подана спроба дослідження хворіб украӥнських повстанців з використанням методів історичної антропологіï. Проаналізована широка база джерел особистого походження, на основі яких можна вивчати історію повсякдення. Автор показує, щио, окрім безпосередньої небезпеки під час бойових дій, учасники українського визвольного руху на Закерзонні зазнавали багатьох інших небезпек. Проаналізований вплив на здоров'я повстанців та підпільників різноманітних захворювань та недуг. Поданий також опис методів повстанського лікування та своєрідного ставлення українських комбатантів до хвороб.

Ключові слова: УПА, ОУН, Закерзоння, підпілля, хвороби, медицина, лікування

Jim. 22.

Vadym PROKOPOV, Postgraduate student of the Department of History of Ukraine, Oles' Honchar Dnipro National University, Researcher at the Institute for Social Studies (Dnipro,Ukraine) vadim.prokopov@gmail.com

\section{DESEASES AND THEIR TREATMENT IN THE LIFE O UKRAINIAN INSURGENTS OF THE TRANSCURZONIA (1944 - 1947)}

The article deals with diseases and illnesses of participants of the movement of the Organization of Ukrainian Nationalists (OUN) and the Ukrainian Insurgent Army (UPA) within the territory behind the Curzon Line (alias Zakerzonnia or Transcurzonia) in 1944 - 1947. The article is based on a solid source base of mostly personal origin, memoirs and diaries of UPA's companies. A brief review of historiography and historical sources are also represented. The author starts with few theoretical remarks on description of everyday life. Most of contemporary research papers study external questions of medicine of UPA and OUN, for example, the organization and functioning of the Ukrainian underground health service. The author emphasizes that it is very important for the contemporary Ukrainian history to use the methods and approaches of historical anthropology.

The article underlines that Ukrainian insurgents struggled for their own health, and tried to treat diseases. The underground paramedics did everything possible for their patients. In most cases sick partisans were placed into sanitary posts in villages and special underground bunkers. Besides, the medical personnel in the units of the UPA Medical Service was insufficiently professional. Sometimes doctors visited sick UPA soldiers in forest hospitals or temporary medical stations set up in villages. In some instances, wounded or sick insurgents and underground workers, especially women, were given beds in city hospital. One of the most important tasks for UPA soldiers and medics was to obtain medications, bandages and other medical supplies.

The author also briefly describes the instances of extremely hard marches through snowy territories and consequent terrible frostbites of the Ukrainian partisans. The description of most spread diseases is also presented in this article. Venereal diseases among the soldiers of Ukrainian Insurgent Army and the attitude of officers to these incidents are also scrutinized in this article. Certain attention is paid to the studying of typhus and fever among the Ukrainian insurgents and unsanitary conditions of the liberation struggle. Other illnesses which the author often mentions in the article include various types of gastroenteritis, vitamin deficiency, scabies, impetigo, pediculosis and pneumonia, flu, and inflammation of the joints. When drugs were lacking, home remedies had to be applied. For example, a primitive form of immunotherapy which consisted of injecting the patient with the substance made after a prescription from rural pharmacists.

In conclusion, the author emphasizes that the extreme conditions of guerrilla warfare increased the risk of appearance of heterogeneous infectious diseases. The Ukrainian insurgents had to fight for their country in unsatisfactory hygienic conditions, which was an additional factor in the spread of illnesses.

Key words: UPA, OUN, Zakerzonnia (Transcurzonia), underground, medicine, disease, treatment

Ref. 22. 
Вадим ПРОКОПОВ,

аспирант кафедры истории Украины Днепровского национального университета им. Олеся Гончара Научный сотрудник Института общественных исследований (Днепр, Украина) vadim.prokopov@gmail.com

\section{БОЛЕЗНИ И ИХ ЛЕЧЕНИЕ В ЖИЗНИ УКРАИНСКИХ ПОВСТАНЦЕВ ЗАКЕРЗОНЬЯ (1944 - 1947 ГГ.)}

В статье представлена попытка исследования болезней украинских повстанцев с использованием методов исторической антропологии. Проанализирована иирокая база источников личного происхождения, на основе которых можно изучать историю повседневности. Автор показывает, что кроме непосредственной опасности во время боевых действий участники украинского освободительного движения на Закерзонье испьтывали многих других опасностей. Проанализировано влияние на здоровье повстаниев и подпольщиков различных заболеваний и недугов. Представлено также описание методов повстанческого лечения и своеобразного отношения украинских комбатантов к болезням.

Ключевые слова: УПА, ОУН, Закерзонья, подполья, болезни, медицина, лечение.

Лит. 22.

Постановка проблеми. Будь-які військові дії завжди супроводжуються травмами та пораненнями учасників - комбатантів. Залежно від стану матеріального забезпечення воюючих армій, обставин та кліматичних умов, в яких ведеться війна, вояки піддаються різним небезпекам для життя і здоров'я. Одними з головних складових повсякдення вояка на війні $є$ хвороби, поранення та медичне забезпечення, які в екстремальних умовах стають чи не найважливішими для виживання.

У сучасній ситуації військового конфлікту на Сході України для української армії, суспільства, влади стає як ніколи актуальним досвід поколінь у бойових діях минулої доби. Належне вивчення та висвітлення досвіду вояків УПА допоможе уникнути проблем, з якими стикалися партизани 1940-х рр., краще зрозуміти, передовсім психологічний стан сьогоднішнього вояка. I, врешті, бути готовим до викликів війни.

Аналіз досліджень. Тема медицини в УПА вже ставала темою досліджень. Однак зазвичай дослідники вивчають іiі зовнішній, часто формальний бік - формування медично-санітарної справи, організація медичної допомоги. Найбільш глибоко питання дослідив Аретій Кравець, висвітлюючи становлення і розвиток Українського Червоного хреста та служби здоров’я. Його робота $є$ чи не єдиною монографією з тематики [10, 177]. На проблемах організації медичної служби в УПА також зосередила свою увагу Галина Стародубець [20, 199-202] Окрім офіційних фактів, повсякденні аспекти медичного обслуговування згадані у роботі Марії Срібної, вона описала умови життя в санітарних криївках, раціон харчування хворих [19]. Специфіка догляду за хворими жінками-санітарками коротко заторкнута у статті Ольги Бежук [3, 217-225]. Наразі найбільш антропологічною є лише стаття Ярослава Антонюка [1], в якій з точки зору повсякденної історії поданий нарис про повстанських дантистів та проблему хворих зубів та їх лікування у воїнів УПА і ОУН. У пропонованій статті про матеріальні аспекти повсякденного життя вояків УПА поміж інших аспектів поданий короткий нарис проблематики хворіб та поранень в УПА і ОУН на Закерзонні [18].

Як бачимо, повсякденні аспекти вивчення медичної служби є досі невідомими та мало вивченими. Перспективними напрямами досліджень виступає антропологізація історії, розгляд внутрішніх переживань через поранення та травм людей українського підпілля; практик поведінки повстанців в таких ситуаціях у повсякденному вимірі; варіанти лікування у бойових умовах та прихисток поранених.

Метою статті $є$ демонстрація різноманіття хворіб та недуг, яких зазнавали учасники визвольного руху на Закерзонні від перебування в екстремальній ситуації - бою, втечі, переховуванні. Подивимось, як українські комбатанти Закерзоння намагались лікуватися та зберігати здоров'я. Не торкатимемось теми поранення та інших бойових травм, що варті окремого дослідження. У статті будемо застосовувати міждисциплінарні підходи воєнно-історичної антропології та воєнної психології. 
Джерела. Основним джерелом у дослідженні є его-документи - денники сотень, спогади та мемуари. Незважаючи на поширену думку про наративні джерела як про менш достовірні, другорядні, ми звертаємо увагу на їх незамінність при вивченні повсякдення. Так само вони першочергово важливі в описі такого явища, як психологія комбатанта - людини, що бере участь у бойових діях. Документальні джерела - офіційні звіти, інструкції будь-якої з воюючих сторін не ілюструють внутрішній світ людини, іiї переживання на полі бою, а часто залишаються байдужими до повсякденних турбот та прикростей комбатанта - поранень, обморожень, нервових та психічних виснажень. Матеріали допитів арештованих повстанців урядовими органами безпеки також не демонструють цих явищ і часто є викривленими самими підозрюваними.

Виклад основного матеріалу. Отже, спочатку розглянемо різні хвороби, стисло описуючи способи боротьби з ними. Наприкінці покажемо детальніше систему повстанської медицини. Продемонструємо своєрідні лікувальні практики учасників визвольного руху на Закерзонні.

Хвороби. Зазвичай у великому скупченні людей, особливо в армії, коли багато чоловіків живуть та харчуються в одному місці, підвищується вірогідність захворювань. У партизанських умовах гігієнічні умови були зазвичай незадовільними. Протягом довгого часу вояки не мали змоги помитися та змінити білизну.

Бруд та воші створювали грунт для розвитку хворіб, особливо тифу [8, 170]. У сотнях час від часу спалахувала ця хвороба, також хворіли місцеві люди, а ліків не було $[14,383]$. Сдиною полегшою було те, що хворі перебували у відносній «безпеці» від ворогів, бо поляків відлякували написи «тиф» на хатах $[6,327]$. Інфекцію повстанські санітари лікували сирими яйцями та відваром з гілля верби, лікарі робили уколи наявною вакциною $[6,265]$. У сотнях проводилися також профілактичні щеплення проти черевного тифу [14, 477].

Найбільш дошкульним плямистий тиф виявився на Лемківщині навесні 1945 р. серед стрільців сотні «Веселого» $[14,137]$. Справжніх ліків не було, і вояки самі прали білизну та виварювали iii в окропі, не маючи навіть мила $[11,125-128 ; 12,97-98]$. У сільській школі була влаштована купіль для хворих, їх самих помістили в окремих хатах, а також дезінфікувалися особисті речі. Після ретельного лікування майже вся сотня одужала, не вижили лише троє [4, 76-77].

У таборі УПА на Буковому Берді багато вояків страждали від шлункових розладів через велику кількість споживання волового товщу. Після застереження санітарної служби кухарі зменшили вміст жиру в стравах [11, 118,123-129; 5, 22].

Унаслідок поганого харчування, антисанітарних умов у повстанців поширювалася дизентерія, зокрема під час довготривалих рейдів $[22,51 ; 11,128]$. Дизентерію вояки називали «червінкою» та іноді, чомусь, лікували печеною картоплею $[13,272]$. Важкохворих відсилали до шпиталів та сіл на опіку лікарям та санітарам $[11,129 ; 14,383,425]$ Для догляду за хворими командування наказало будувати шпиталі [13, 272; 6, 49].

Раціон харчування без достатньої кількості вітамінів спричиняв у повстанців цингу. Цю недугу лікували недостиглою ожиною, цибулею та ячмінною кавою $[12,62 ; 11,118]$. Цинга часто спалахувала навесні. Повстанські санітари використовували настоянку йоду і гліцерину, лікування якими не було ефективним. Іншим засобом був вивар з молодого чатиння сосни, який невдовзі почав діяти. 3 появою зелені хворі вживали лісовий щавель, листя барбарису та інше [8, 49, 40].

Життя без постійного теплого прихистку так само позначалось на здоров’ї. В умовах холодної зими та вологої весни тіла повстанців обсипали чиряки, що заважало роботі. Цей стан здоров'я «дуже дошкуляв та болів» $[15,180 ; 14,497 ; 22,65]$.

Підпільники хворіли на запалення суглобів. Таких звільняли від обов'язків служби і давали змогу лікуватися протягом кількох місяців. Однак навіть після позірного одужання вояки ще довго не могли стати повноцінно до лав [4, 164, 237-238]. Траплялися випадки запалення легень $[11,124 ; 13,287]$ та грипу [17, 185], які також намагалися лікувати.

Час від часу серед повстанців поширювались хвороби шкіри, такі як сверблячка або короста. Хворих відіслали до сіл, де їх ізолювали в окремому інфекційному відділі [8, 142-143].

Найпоширенішою «пекучою» проблемою були воші. Люди, зайняті активністю в підпіллі чи партизанських акціях, іноді не мали часу для боротьби зі шкідниками $[15,205]$. При великих скупченнях людей без регулярних водних процедур у білизні та одежі дуже швидко множилися паразити. 
У лісах гігієнічні умови були особливо нестерпними. Командири намагались робити санітарні перегляди та організовували боротьбу з паразитами. 3 метою зменшення їх кількості деякі сотенні та курінні наказували голитися під нуль [16, 829; 17, 168-169,178-179]. Уранці повстанці виходили на полювання за «партизанами». Роздягнувшись до гола, стрільці обшукували свою білизну й одяг [8, 89-90]. В деяких відділах повстанці зауважили, що мурахи їдять вошей, і залишали їм на деякий час одяг для «очищення», однак цей засіб діяв недовго [8, 155-156].

Венеричні хвороби. Як відомо, вони розповсюджуються у воєнний час у будь-яких арміях та прилеглих до бойових дій територіях. В УПА до венерично хворих, за спогадами учасників, ставилися доволі суворо, оскільки неможливо було лікуватись у польових умовах. Набагато загрозливішою була небезпека зголошення недужого до співпраці з владою в обмін на лікування. У випадку хворого командира адміністративної боївки «Зими», про який оповідає Іван Лико, підпілля наражалось на небезпеку викриття цілої районної мережі ОУН. Провідник району «Чорнота» постановив ліквідувати необачного повстанця і невдовзі наказ було виконано [15, 209-211, 219-221].

У сотні «Яра» (колишній командир «Барон») було виявлено трьох венерично хворих жандармів. 3 огляду на неможливість лікування та можливу здачу полякам польовий суд засудив їх на кару смерті: «Вирок виконано перед цілою сотнею». 3 того часу в сотні проводились щоранку «шванцпаради» (перегляд бійців в оголеному вигляді), що мали виявити інших хворих [6, 327].

Курінний командир «Рен» проголосив в одному з усних наказів, що вояка, в якого виявиться венерична недуга, чекає присуд смерті. Обгрунтовував це тим, що такий наказ існував в інших відділах УПА. Не маючи прямого зв’язку ГВШ УПА, «Рен» спирався на інформацію від вояків УПА з інших теренів. Однак курінний лікар М. Ріпецький «Горислав» 3 такою думкою не погоджувався. У лемківському таборі на Буковому Берді «Горислав» виявив трьох венерично хворих, але для «Рена» причину звільнення з лав повстанців подавав іншу $[11,116]$.

Офіційні інструкції теренових провідників ОУН з приводу венеричних хвороб вказували, що хворих слід лікувати переважно за їх рахунок, у надзвичайних випадках коштом організації. Приписувалося також влаштовувати лікування місцевих жителів. Працівники Служби здоров'я мали розслідувати, хто став розсадником інфекції, та всіляко їх блокувати. У разі «навмисного зараження» 3 такими особами наказувалось «поступати безоглядно» [2]. Незважаючи на часом жорстоке ставлення до венерично хворих, підпільні санітари все ж намагались знайти якісь ліки та організувати лікування $[16,696]$. На півночі Закерзоння курінний Іван Шпонтак «Залізняк» організував для венерично хворих «спецланку» 3 п’ятьох осіб. Їх головне завдання полягало за будь-якої нагоди здобувати ліки. Іван Кордан пише, що ці хворі віддали життя у боях [9, 112-113].

Сотенного командира «Біса» курінний «Залізняк» звільнив від обов’язків як венерично хворого, а він, вірогідно, пішов на лікування та зголосився до співпраці з ворогом [16, 395].

Обмороження. Повстанцям в умовах партизанського бою доводилося швидко залишати місце постою під тиском ворога. Іноді вони не встигали одягнутись - і вибігали зі своєї схованки в чому були. В холодну пору року це несло загрозу обмороження. Втікаючи від ворожого війська, повстанці могли бігти по снігу босими. Після завершення бою, через деякий час вояк переставав відчувати ноги. «Віддер від сорочки рукави, позавивав трохи ноги й пішов лісом в напрямку села Березниці, куди було 9 кілометрів», - писав повстанець «Лісовий». Такі пригоди клали вояків на декілька місяців на лікування [4, 132-133].

Стрілець «Відвабний» вибіг у білизні та легкому светрі з бункера, втікаючи від погоні, отримав поранення. В результаті бойового виснаження та больового шоку втратив почуття реальності: «натискав свої пальці на ногах. 3 них поробились льодові соплі, які під натиском рук відламлювались, як патички. Ми відірвали його від тієї макабричної забави й пообмотували йому ноги» $[4,138]$.

Узимку 1946 - 1947 pp. повстанцям через постійні облави польського війська доводилось ночувати в лісі, що викликало в багатьох серйозні обмороження кінцівок та застуди, у тому числі 3 летальними випадками [15, 230-234].

Тривалі цілоденні марші сотні на сильному морозі, коли вояки проходили по 30 км, неабияк загрожували здоров’ю. Чотовий УПА О. Конопадський згадував: «Багато стрільців відморозило собі пальці на руках, вуха, носи і лиця. Я нарахував двадцять трьох обморожених. Надвечір решт- 
ками сил (вже багатьох стрільців треба було вести і нести) ми дійшли до Горішнього Вислока» $[13,314]$. Навіть під час постоїв, коли довгий час стрільці були на чергуваннях, обморожували руки, ноги та вуха $[6,321]$.

Такі обмороження призводили до пухирів, що тріскали, і на їх місці залишалися глибокі рани. Багато хто не міг ставати на ноги, і сотенні санітари на постоях у селі лікували обморожених в гарячій воді з борною кислотою, або сироваткою. Такі процедури давали добрі результати [8, 160-161].

Лікування хвороб. В УПА на Закерзонні фахові лікарі були рідкістю. Більшість медперсоналу складали санітари та медсестри, які пройшли короткотривалі курси. Іноді траплялися курйозні ситуації, коли людина представлялась лікарем чи іiі так сприймали, однак такою не була. Такий випадок стався на Перемищині з лікарем «Вуйком», який насправді лікарем не був і декілька разів виявляв свою некомпетентність, інколи навіть шкодячи ще більше здоров'ю вояків. Його шарлатанство врешті було розкрите $[22,216]$. Хоча сотенний «Хрін» згадує цей випадок трохи інакше, відзначаючи, що «Вуйко», натомість, був здібним організатором медичної служби в підпіллі [13, 181]. Інші повстанці з цього терену згадують, як «Вуйко» робив вдалі операції одразу після бою [6, 265].

Повстанські санітари надавали допомогу також цивільному населенню - селянам, у яких квартирували. У цьому проявлялася співпраця селян та комбатантів. Про таких санітарів в селі люди швидко дізнавались і вважали їх за лікарів, ходили до них на лікування. «Лікував коросту, давав людям масть, зроблену повстанськими фармацевтами, це була смола $з$ сосни і «тол», який сапери наші діставали з залишків бомб та гарматних стрілен» $[8,176]$.

Хворих вояків найчастіше переховували місцеві селяни у своїх помешканнях або в криївках під ними [4, 237-238]. Очевидно, повстанець на лікуванні наражав на небезпеку людей, які за ними доглядали. Іноді хворі потрапляли в полон, не встигнувши покінчити з собою [13, 287]. До важко хворих приходили повстанські санітари та медсестри, робили ін'єкції [4, 237-238].

Деякі підпільники під час хворіб переховувались у лісі в колибах та землянках, маючи одного чи декількох доглядальників-охоронців $[6,49]$. Хворі підпільниці, особливо які мали фальшиві документи, могли лікуватися у пансіонатах в малих містечках, місця в яких організовувались через знайомих [21, 152-153]. Взагалі, жінки-підпільниці мали у порівнянні з чоловіками більше можливостей подорожувати, не викликаючи підозр з боку влади.

Повстанці не гребували користуватись послугами сільських знахарів. Підпільнику «Цяпці» від хворого шлунку народний лікар дав «зілля гірке, як полин», яке все ж допомагало [22, 178]. Відморожені ноги лікували у сільських бабусь, які прикладали мазі та кролячі шкірки $[6,266]$. Повстанці воліли лікуватись будь-яким чином, аби не йти до підземних шпиталів.

У питанні з медикаментами - ліками та перев'язувальним матеріалом у середовищі визвольного руху відчувалась постійна нестача $[14,365,383,425]$. Повстанці використовували будьяку нагоду для поповнення своїх аптечних запасів. Під час нападів на залоги польської міліції у містечках Закерзоння повстанці намагались здобути якомога більше медикаментів [4, 123].

Інколи самі напади сотень УПА на містечка обгрунтовувалися потребою ліків, бандажів та тканини. Так, сотні Перемиського району напали на м. Дубецько, де з аптек та крамниць здобули потрібні матеріали [6, 331-332].

Підпілля намагалось отримати ліки й легальним шляхом. Але до великих міст, як Сянок чи Лісько, відправити своїх людей для закупівлі медикаментів чи бинтів не могли, бо польська влада контролювала такі закупівлі, й покупців могли одразу арештувати. В цій ситуації підпілля покладалося на контрабандистів - «пачкарів», які купували товар у Польщі та везли у Словаччину. 3 їх допомогою можна було налагодити постачання потрібних речей і навіть листування з родичами за кордоном [13, 288].

За відсутності польської влади підпілля організовувало у селах власне виробництво ліків та бандажів для перев'язки ран $[8,34]$. Під час відпочинку сотенні санітари намагались використовувати природні речовини і збирали інгредієнти для ліків у лісі: «Я взявся до роботи: виготовив мазь $з$ бджолиного воску з домішками смерекової живиці і масла, з додатком спирту. Тим мазали відморожені частини тіла» $[8,154]$.

Висновки. Як бачимо, в екстремальних умовах ведення партизанської боротьби ризик появи різнорідних інфекційних уражень і хвороб підвищувався у рази. Українським повстанцям дово- 
дилося воювати у незадовільних гігієнічних умовах, що було додатковим фактором поширення недуг. Нестача матеріального забезпечення, передовсім теплого одягу взимку, також давалося взнаки. В екзистенційній для людини ситуації загрози смерті від кулі чи в полоні, воїни УПА та ОУН обирали сповнений ризику варіант порятунку, як втеча без верхнього одягу та взуття зимою 3 подальшим обмороженням. Етично важкими і неоднозначними були рішення деяких командирів про ліквідацію венерично хворого соратника. Рух українців за визволення своєї батьківщини для його учасників часто ставав боротьбою за виживання. Незважаючи на несприятливі обставини, повстансько-підпільне середовище намагалось боротися за здоров'я власних членів у міру доступних сил та засобів.

\section{СПИСОК ВИКОРИСТАНИХ ДЖЕРЕЛ І ЛІТЕРАТУРИ}

1. Антонюк Я. «Повстанські дантисти»: лікування зубів у підпіллі ОУН-УПА / Я. Антонюк // Актуальні питання суспільних наук та історії медицини. - 2016. - № 2. - С. 65-72.

2. Архів Цетру досліджень визвольного руху - Ф. 9. - Т. 12. - арк. 1-2. - [Електронний ресурс]. Режим доступу: URL: http://avr.org.ua/index.php/viewDoc/8922/

3. Бежук О. М. Матурантки Українського інституту для дівчат у Перемишлі у визвольному русі ОУНУПА / О. М. Бежук // Науковий вісник Львівського національного університету ветеринарної медицини та біотехнологій ім. Гжицького. - 2014. - Т. 16, № 2(5). - С. 217-225.

4. «В рядах УПА» збірка споминів був. вояків УПА [за ред П. Мірчука, В. Давиденка]. - Нью Йорк, «Dnipro», 1957. $-352 \mathrm{c}$.

5. Дмитрик І. Записки українського повстанця (У лісах лемківщини) / І. Дмитрик. - Л.: «Червона Калина», 1992. - 162 c.

6. Закерзоння. Спогади вояків Української повстанської армії / [Ред., упорядн. Б. Гук]. - Варшава: «Тирса», 1994. - Т. 1. - 440 с.

7. Йовик І. Нескорена армія / І. Йовик. - К.: МП «Леся», 1995. - 320 с.

8. Кметь Є. Спогади. Любачивщина на шляху боротьби / Є. Кметь. - Дніпропетровськ: Видавництво журнал «Бористен», 2000. - 230 с.

9. Кордан А. Один набій з набійниці. Спомини вояка УПА з куреня «Залізняка» / [упоряд. М. Дубас]. Торонто; Львів, 2006. - 243 с.

10. Кравець А. Медики у визвольних змаганнях українського народу (від Українського Червоного Хреста до Служби Здоров’я УПА) / А. Кравець. - Л., 2010. - 177 с.

11. Літопис Української Повстанської Армії / [ред. М. Ріпецький]. - Торонто; Львів, 1992 - 1993. Т. 23: Медична опіка в УПА. -478 с.

12. Літопис Української Повстанської Армії. - Т. 29: Гарасимів І. («Палій») 3 юнацьких - мрій в ряди УПА. / [ред. І. Тимочко-Камінська, С. Голяш]. - Торонто; Львів, 1999. - 330 с.

13. Літопис Української Повстанської Армії. - Т. 30: Стебельський С. («Хрін»), Конопадський О. («Островерх») Крізь сміх заліза. / [ред. П. Потічний]. - Торонто; Л., - 2000. - 552 с.

14. Літопис Української Повстанської Армії. - Т. 33: Тактичний Відтинок УПА 26-й «Лемко»: Лемківщина і Перемищина (Документи і матеріали)./ [ред. П. Потічний, І. Лико]. - Торонто; Л., 2001. - 900 с.

15. Літопис Української Повстанської Армії. - Т. 37: Лико І. («Скала», «Богдан») На грані мрії і дійсности: Спогади підпільника. На грані двох світів: Спогади. 1945 - 1955. / [ред. П. Потічний]. - Торонто; Л., 2002.- 644 с.

16. Літопис Української Повстанської Армії. - Т. 39: Тактичний відтинок УПА 28-й «Данилів» Холмщина і Підляшшя (Документи і матеріали). / ред. П. Потічний. - Торонто; Л., 2003. - 1058 с.

17. Літопис Української Повстанської Армії. - Т. 40: Тактичний відтинок 27-й «Бастіон»: Любачівщина, Томашівщина, Ярославщина (Документи і матеріали). / ред. П. Потічний. - Торонто; Л., 2004. - 600 с.

18. Прокопов В. Матеріальний аспект повсякденного життя учасників руху ОУН та УПА на Закерзонні (1943 - 1947 рр.) / В. Прокопов// Гуманітарний журнал / Нац. гірн. ун-т. - Дніпропетровськ - 2015. - № 3-4. - C. 127-138.

19. Срібна М. Підпільний Український Червоний Хрест в загонах Української Повстанської Армії у роки Другої світової війни / М. А. Срібна // Історія і біографістика. Електронне наукове фахове видання міжвідомчий тематичний збірник. - 2011. - No 4. - [Електронний ресурc] - Режим доступу: URL: http://www. drgene.ru/e - journals/inb/2011 - 4/index.html

20. Стародубець Г. Організація медико-санітарної служби у повстанському запіллі (друга половина 1943 - 1944 рр.) / Г. Стародубець // Наукові записки з української історії: Збірник наукових статей. - Переяслав-Хмельницький, 2005. - Вип. 17. - С. 199-204. 
21. Тимочко І. Моя одиссея / І. Тимочко. - Варшава: Вид-во Український Архів, 2005. - 384 с.

22. Цяпка Д. Горить Ліс! / Д. Цяпка. - Лондон: Укр. Вид. Спілка, 1975. - 395 с.

\section{REFERENCES}

1. Antoniuk Ya. «Povstanski dantysty»: likuvannia zubiv u pidpilli OUN-UPA / Ya. Antoniuk // Aktualni pytannia suspilnykh nauk ta istorii medytsyny. -2016 . - № 2. - S. 65-72.

2. Arkhiv Tsetru doslidzhen vyzvolnoho rukhu - F. 9. - T. 12. - ark. 1-2. - [Elektronnyi resurs]. - Rezhym dostupu: URL: http://avr.org.ua/index.php/viewDoc/8922/

3. Bezhuk O. M. Maturantky Ukrainskoho instytutu dlia divchat u Peremyshli u vyzvolnomu rusi OUN-UPA / O. M. Bezhuk // Naukovyi visnyk Lvivskoho natsionalnoho universytetu veterynarnoi medytsyny ta biotekhnolohii im. Gzhytskoho. - 2014. - T. 16, № 2(5). - S. 217-225.

4. «V riadakh UPA» zbirka spomyniv buv. voiakiv UPA [za red P. Mirchuka, V. Davydenka]. - Niu York, «Dnipro», 1957. - $352 \mathrm{~s}$.

5. Dmytryk I. Zapysky ukrainskoho povstantsia (U lisakh lemkivshchyny) / I. Dmytryk. - L.: «Chervona Kalyna», 1992. - $162 \mathrm{~s}$.

6. Zakerzonnia. Spohady voiakiv Ukrainskoi povstanskoi armii / [Red., uporiadn. B. Huk]. - Varshava: «Tyrsa», 1994. - T. 1. $-440 \mathrm{~s}$.

7. Iovyk I. Neskorena armiia / I. Yovyk. - K.: MP «Lesia», 1995. - 320 s.

8. Kmet Ye. Spohady. Liubachyvshchyna na shliakhu borotby/Ye. Kmet. - Dnipropetrovsk: Vydavnytstvo zhurnal «Borysten», 2000. - $230 \mathrm{~s}$.

9. Kordan A. Odyn nabii z nabiinytsi. Spomyny voiaka UPA z kurenia «Zalizniaka» / [uporiad. M. Dubas]. Toronto; Lviv, 2006. - $243 \mathrm{~s}$.

10. Kravets A. Medyky u vyzvolnykh zmahanniakh ukrainskoho narodu (vid Ukrainskoho Chervonoho Khresta do Sluzhby Zdorovia UPA) / A. Kravets. - L., 2010. - 177 s.

11. Litopys Ukrainskoi Povstanskoi Armii / [red. M. Ripetskyi]. - Toronto; Lviv, 1992 - 1993. - T. 23: Medychna opika v UPA. $-478 \mathrm{~s}$.

12. Litopys Ukrainskoi Povstanskoi Armii. - T. 29: Harasymiv I. («Palii») Z yunatskykh - mrii v riady UPA. / [red. I. Tymochko-Kaminska, S. Holiash]. - Toronto; Lviv, 1999. - 330 s.

13. Litopys Ukrainskoi Povstanskoi Armii. - T. 30: Stebelskyi S. («Khrin»), Konopadskyi O. («Ostroverkh») Kriz smikh zaliza. / [red. P. Potichnyi]. - Toronto; L., - 2000. - 552 s.

14. Litopys Ukrainskoi Povstanskoi Armii. - T. 33: Taktychnyi Vidtynok UPA 26-y «Lemko»: Lemkivshchyna i Peremyshchyna (Dokumenty i materialy)./ [red. P. Potichnyi, I. Lyko]. - Toronto; L., 2001. - 900 s.

15. Litopys Ukrainskoi Povstanskoi Armii. - T. 37: Lyko I. («Skala», «Bohdan») Na hrani mrii i diisnosty: Spohady pidpilnyka. Na hrani dvokh svitiv: Spohady. 1945 - 1955. / [red. P. Potichnyi]. - Toronto; L., 2002.- 644 s.

16. Litopys Ukrainskoi Povstanskoi Armii. - T. 39: Taktychnyi vidtynok UPA 28-y «Danyliv» Kholmshchyna i Pidliashshia (Dokumenty i materialy). / red. P. Potichnyi. - Toronto; L., 2003. - 1058 s.

17. Litopys Ukrainskoi Povstanskoi Armii. - T. 40: Taktychnyi vidtynok 27-y «Bastion»: Liubachivshchyna, Tomashivshchyna, Yaroslavshchyna (Dokumenty i materialy). / red. P. Potichnyi. - Toronto; L., 2004. - 600 s.

18. Prokopov V. Materialnyi aspekt povsiakdennoho zhyttia uchasnykiv rukhu OUN ta UPA na Zakerzonni (1943 - 1947 rr.) / V. Prokopov // Humanitarnyi zhurnal / Nats. hirn. un-t. - Dnipropetrovsk - 2015. - № 3-4. S. $127-138$.

19. Sribna M. Pidpilnyi Ukrainskyi Chervonyi Khrest v zahonakh Ukrainskoi Povstanskoi Armii u roky Druhoi svitovoi viiny / M. A. Sribna // Istoriia i biohrafistyka. Elektronne naukove fakhove vydannia - mizhvidomchyi tematychnyi zbirnyk. - 2011. - No 4. - [Elektronnyi resurs] - Rezhym dostupu: URL: http://www.drgene.ru/e journals/inb/2011 - 4/index.html

20. Starodubets H. Orhanizatsiia medyko-sanitarnoi sluzhby u povstanskomu zapilli (druha polovyna 1943 - 1944 rr.) / H. Starodubets // Naukovi zapysky z ukrainskoi istorii: Zbirnyk naukovykh statei. - PereiaslavKhmelnytskyi, 2005. - Vyp. 17. - S. 199-204.

21. Tymochko I. Moia odysseia / I. Tymochko. - Varshava: Vyd-vo Ukrainskyi Arkhiv, 2005. - 384 s.

22. Tsiapka D. Horyt Lis! / D. Tsiapka. - London: Ukr. Vyd. Spilka, 1975. - 395 s. 